\title{
Development and future perspectives of a humanitarian forensic programme: the committee on missing persons in Cyprus example
}

\author{
Maria Ktori ${ }^{1,2,3^{*}}$ and Gülseren Baranhan ${ }^{4}$
}

\begin{abstract}
Background: In 1981, the Committee on Missing Persons in Cyprus (CMP) was established with a clear purpose: to determine the fate of the missing Greek and Turkish Cypriots who disappeared during the periods 1963-64 and 1974. Following many years of investigations and negotiations, such as on a mutually agreed list of 2001 missing persons (493 Turkish Cypriots and 1508 Greek Cypriots), the CMP officially began its operational phase in 2006 with a small number of Greek Cypriot and Turkish Cypriot scientists.

Methods: This paper presents and analyses the development of the programme, the ways of providing assistance to other countries, and how the programme has influenced local and regional capacity. To do so, the authors performed qualitative and quantitative analyses to assess the programme accurately (annual staff numbers, annual excavations, exhumations and identifications, applied field and lab methods, internship and training programmes).

Conclusions: The results show that the CMP has established a successful humanitarian programme, serving as a model for cooperation in a post-conflict environment. Since 2006, the team of scientists has grown in both numbers and experience, while the CMP has developed into a key player in the field of human identification that is able to provide expertise and technical assistance at a regional level. Ultimately, the authors were able to elucidate the current prospects and future perspectives of the programme to provide a holistic view to readers.
\end{abstract}

Keywords: Missing Persons, Cyprus, Identification Programme, Humanitarian Forensics

\section{Background}

The forensic sciences can be defined as the unification of different and vibrant disciplines employed in resolving legal cases (Ubelaker 2015), and their defining principle is "the situation where the dead teach the living" (Rathbun and Buikstra 1984). The origins can be traced back to sixteenth-century medical research on the cause and manner of death in military operations, but it was not until 1832 that scientific techniques were applied by James Marsh in solving a murder case of arsenic poisoning; this was the first true forensic sciences case. Developments in the field continued and the application of DNA analyses for

\footnotetext{
* Correspondence: eleanorofaquitane@hotmail.com

${ }^{1}$ Cardiff University, Cardiff, UK

${ }^{2}$ University of Cyprus, Nicosia, Cyprus

Full list of author information is available at the end of the article
}

criminal cases was a real breakthrough in the 1980s as Alex Jeffery's work on the mammalian myoglobin gene cluster and its individuality was employed in solving a double rape murder case in Britain (James and Nordby 2003).

Physical anthropology played an important role from the inception of the field of forensic sciences (Snow 1982). The role of physical anthropologists quickly expanded into the identification process of the dead during times of war, thus raising the visibility of anthropology in the forensic community (James and Nordby 2003). The dawn of the twentieth century witnessed two of the most serious conflicts in human history, the First and Second World Wars. The World Wars had international influence, and it is not accidental that the first investigation of war crimes occurred after the end of World War I, at the 1919 Versailles Peace Conference (La Haye 2008). 
Despite the severity of the two World Wars, the formation of international tribunals, the United Nations resolutions on the definition of missing person, enforced disappearances were only recognised as a crime against humanity in 2002 (United Nations 1998).

Considering the importance of the matter, the forensic sciences, particularly forensic anthropology, have been employed in human rights investigations. Such investigations have gone beyond the missing in armed conflicts and developed further within the framework of political violence (Fondebrider 2015). The military dictatorships of 1980s Latin America gave the necessary impetus for the formation of the Equipo Argentino de Antropología Forense (EAAF, Argentine Forensic Anthropology Team) (Doretti and Snow 2008). The Argentinean efforts gained international acclaim and raised awareness of such problems to the degree that more forensic investigation teams were established in other countries. These international teams were also actively involved in the establishment of reliable and rigorous procedures (Fondebrider and Scheinsohn 2015), developed by forensic experts to provide protocols in the collection of forensic evidence so that the perpetrators could be prosecuted (Ousley and Hollinger 2012).

The 1990s Balkan crisis and Yugoslav Wars resulted in the establishment of the International Criminal Tribunal for the Former Yugoslavia, which initiated a large-scale intensive investigation of mass graves, with significant contributions by the Physicians for Human Rights (Fondebrider 2015).(Fondebrider and Scheinsohn 2015) Shortly afterwards, in 1999, the International Commission on Missing Persons was established and acquired the necessary forensic capacity to identify more than 15,000 missing persons since then (Tidball-Binz 2012). As in the case of the Latin American forensic identification programmes, their European counterparts were conducted for legal purposes, aiming to identify and prosecute the perpetrators of such crimes.

Cyprus suffered from inter-communal fighting in 1963-64 and the events of 1974, which left the island scarred and Cypriot families seeking answers for the fate of more than 2000 missing persons. Between the years 1974 and 1977, the fate of the missing persons was an important discussion point in a series of intercommunal meetings on the problem. During the next 3 years (1977-81), the negotiations continued in Nicosia, Geneva and New York with the aim to establish the Committee on Missing Persons in Cyprus (CMP). The United Nations General Assembly Resolutions issued in 1975, 1977, 1978, 1981, and 1982 are indicative of the importance of establishing such a body. The CMP was ultimately founded in April 1981 under the aegis of the UN. Its unique nature as a humanitarian forensic programme has a singular local, regional and international impact.

\section{Methods}

This paper presents a succinct overview of the CMP's project, from its foundation until today. To do so, the authors performed the following:

a) Archival research regarding the specific historical background related to the CMP;

b) Review of international forensic programmes to present and contextualise the CMP case;

c) Qualitative analysis of the project's establishment and development (2006-16), with the involvement of organisations such as EAAF;

d) Qualitative and quantitative analysis regarding the scientists employed by CMP, as well as the field and lab operations;

e) Qualitative and quantitative analysis of the CMP's internship and training programme;

f) Overview and discussion of the CMP's public outreach on a local and international level.

\section{A decade of humanitarian forensics in Cyprus}

The inter-communal fighting in 1963-64 and the events of 1974 left Cyprus in disarray and mourning for the missing. The numerous missing persons were an important issue from 1974 onwards. The two communities conducted a series of talks during 1975-77 and negotiated further during 1977-81. The result was the establishment of the CMP in 1981 (United Nations 1981), which became the first committee in Cyprus, jointly run by Turkish Cypriots and Greek Cypriots under United Nations auspices.

The CMP consists of three members: the Greek Cypriot and Turkish Cypriot communities are each represented by a Member appointed by their respective leaders, while the Third Member is nominated by the International Committee of the Red Cross (ICRC) and is appointed by the UN Secretary-General. The Committee Members make decisions on the basis of consensus, and the mandate clearly states the CMP's humanitarian mission (Committee on Missing Persons in Cyprus 2015a). One should note that the Committee will never seek or attribute responsibility for the death of a missing person or the circumstances of their death. It will, however, as stated in Article 13, make every effort to compile a comprehensive list regarding each community's missing persons, specifying, as appropriate, whether they are alive or dead and, in the latter case, the approximate time of death.

After its establishment in 1981, the two communities focused on the investigative part regarding the missing, aiming to compile a common official list of the disappeared. The CMP list was agreed upon in the late 1990s and includes 2001 missing persons (493 Turkish Cypriots and 1508 Greek Cypriots). The leaders of the two communities reached an agreement in 1997 to 
provide each other immediately and simultaneously all information already at their disposal on the location of graves of Greek Cypriot and Turkish Cypriot missing persons (Committee on Missing Persons in Cyprus 2015b). This was a significant step forward, enabling the CMP to process the information and prepare accordingly for its operational phase.

In 2004, the Members decided to align with the proposals formulated by the Secretary-General and consider ways to expand the Committee's scope of activity and responsibility. The first steps taken towards this were decisive; the CMP established a timetable aiming to conclude the remaining investigative work on both sides, while relatives were called to give blood samples for the identification process. These efforts were enhanced by inter-communal meetings with the United Nations and the International Committee of the Red Cross (ICRC), facilitated by the Secretary-General. The aim was to finalise the investigation process and proceed to the exhumation and identification operations. In 2006, the leaders of the two communities met with the UN Secretary-General and the CMP Third Member and reaffirmed their commitment to and support of the work of the Committee (Committee on Missing Persons in Cyprus 2006). To that end, the CMP issued an international call for experts and initially partnered with the UK-based forensic organisation INFORCE.

Shortly after, the ICRC proposed that the CMP collaborate with an international organisation that would organize, build and direct the archaeological and anthropological phases of the Project on the Exhumation, Identification, and Return of Remains of Missing Persons. The CMP chose to collaborate with the EAAF, and international forensic experts trained and supervised the scientists until the end of 2007 (Committee on Missing Persons in Cyprus 2015c). The team of scientists was officially named "Bi-Communal Forensic Team - BCFT", and has been known so ever since.

The field operations ran simultaneously with the training and the work carried out at the CMP Anthropological Laboratory (CAL). The excavations and exhumations were conducted all over Cyprus under the supervision of the
EAAF experts (Fig. 1) (EAAF 2009). Since 2008, the EAAF has remained a close collaborator with the CMP, serving as a consultant to the project, and the field and lab teams have operated independently since (Committee on Missing Persons in Cyprus 2015c).

The identification process carried out by the CMP is a very disciplined and demanding procedure, that has evolved significantly since the recommencement of the CMP operations in 2006. The procedure has now been consolidated into the following seven phases: a) antemortem data collection, b) collection of witness information in combination with archival research, c) an archaeological phase, d) an anthropological phase, e) a genetic phase, f) identification, and g) the return and burial of the remains.

\section{a) Antemortem data collection process}

Antemortem data collection is a structured process comparable to international examples. It requires the respective Member's Office to complete a strictly confidential antemortem data form for each missing person, following the ICRC principles. These forms are the basis of the "Antemortem Data Base - Information File for the Identification of Relatives", as all the data and the specific characteristics of a missing or deceased person are catalogued. Previous research has demonstrated the value and importance of artefacts and how they are handled by the CMP scientists, especially at this early stage of the identification process (Moyssi et al. 2016).

b) Collection of witness information in combination with archival research

The antemortem data collection took place after the two conflicts and resulted in a significant amount of information which became a building block of this project, as in other cases of forensic identification programmes (Moyssi et al. 2016). The antemortem data are being enriched further with archival research both locally and abroad.
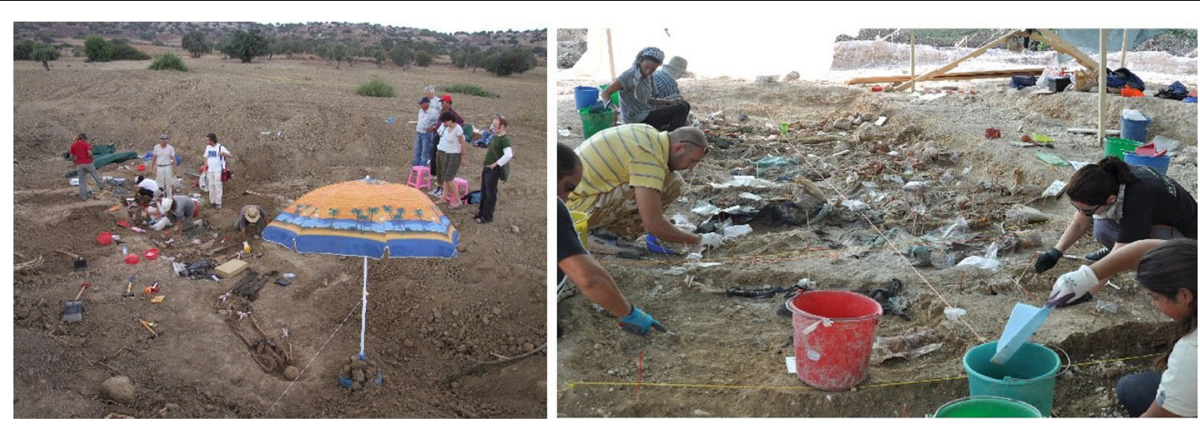

Fig. 1 A mass grave exhumation under the coordination of EAAF in 2008 (left) and a mass grave exhumation in 2016 performed exclusively by the CMP archaeologists (right) 
The very first investigators employed by CMP had firsthand experience of the tragic events, enabling then to empathise more easily with the experiences of the witnesses and the families of the missing. The current, much younger investigators have contributed equally and have been directly facing the problem of the witnesses dying out. In all cases, teams of investigators process the information and visit possible burial sites with the archaeologists and, when possible, the witnesses. This gives the archaeologists the chance to contextualise and clarify everything prior to an excavation.

The CMP faces great challenges regarding witness information, as the witnesses' old age and landscape changes over the years have a negative impact on locating a burial site (Moyssi et al. 2016). Considering the sensitivity of the matter, the CMP has taken action to broaden the investigative efforts. Since August 2016, a team of researchers has undertaken the complex task of conducting an impartial review of archival material from international organisations, domestic authorities and state actors that were present during the two conflicts. It is hoped that this effort will provide new information for the location of burial sites and the successful exhumation of the remaining missing persons, aided by the application of new technologies such as Geographic Information Systems (GIS). The use of GIS will allow the investigators to build a new database to facilitate better management and follow-up of the witness and archival information, which will then assist in the overall investigation process (Committee on Missing Persons in Cyprus 2016a).

\section{c) Archaeological phase}

On-site discussions amongst investigators, scientists and witnesses have proven to be valuable from early on because the archaeologists must assess and draw on the information as to plan the excavation. In 2006, the first archaeological field team began its operations and established that the possible burial sites were more complex than initially thought to be. Each site was different in terms of terrain, location, accessibility, and many more variables which affected the overall operations and the time needed to complete them (Fig. 2). Early excavations demonstrated a discrepancy between the expected exhumation rates and the accuracy of the provided information, which was resolved by hiring more staff and creating more field teams (Fig 3). Each team was composed of two Turkish Cypriot and two Greek Cypriot archaeologists, with one archaeologist acting as Team Leader, along with a heavy equipment operator. The teams were initially coordinated by an EAAF expert; since 2009, they have been coordinated by a Field Coordinator from each community and a Turkish Cypriot Deputy Coordinator since 2016. Currently, there are nine teams, seven operating in the north and two in the south.

The variables previously mentioned persist in all cases, since forensic archaeological excavations are conducted in unconventional environments. These environments became a standard in the CMP archaeological operations, and consequentlytraditional archaeological methods were applied and creatively employed to tackle problems and to address complex excavations, such as those of deep wells (Çeker and Stevens 2015), exhumations of commingled remains and so forth.

The systematization employed by the field teams reduced the contamination across an excavation (Crist 2001) and allowed the collection of contextual information (Dirkmaat and Adovasio 1997), as it is a critical aspect during exhumations (Moyssi et al. 2016). After a comparison between the early and recent field operations, it was evident that the archaeologists were able to overcome any difficulties and complexities during an excavation. The island-wide operations have always been regulated by strict guidelines that adhere to international practices, as reflected in the Field Standard Operating Protocols (SOP). From the initial training under the guidance of the EAAF, the archaeologists have developed consistently and have now reached the desired level of internal capacity which is also reflected in their professional development (Figs. 1, 3).

From this decade of field operations, the archaeologists have excavated and recorded a large number of sites that have produced an equally large amount of data. The exhumations themselves have provided the CMP with crucial data on burial patterns, which have been uploaded on a GIS database and are combined with archival and witness information in order to locate more possible burial sites. Furthermore, the CMP intends to integrate the inspection of possible burial sites during excavations with geophysical methods (e.g. groundpenetrating radar, metal detectors) to provide the archaeologists with a more accurate image of each site and increase the success rate (Committee on Missing Persons in Cyprus 2017a, 2017b).

The great variability and complexity of forensic archaeological sites remains a key factor in adapting and developing the field SOP further. The standard archaeological stages in a CMP forensic excavation have now been consolidated into the following six: a) site risk assessment and preparation of a health and safety plan by the Health \& Safety Coordinator, b) initial documentation of the site, c) intensive pedestrian survey (when the terrain permits it), d) controlled mechanical-aided excavation, e) exhumation (when human remains are encountered), and f) restoration of the area to its prior state. It has previously stressed how landscape alterations affect both the investigation and 


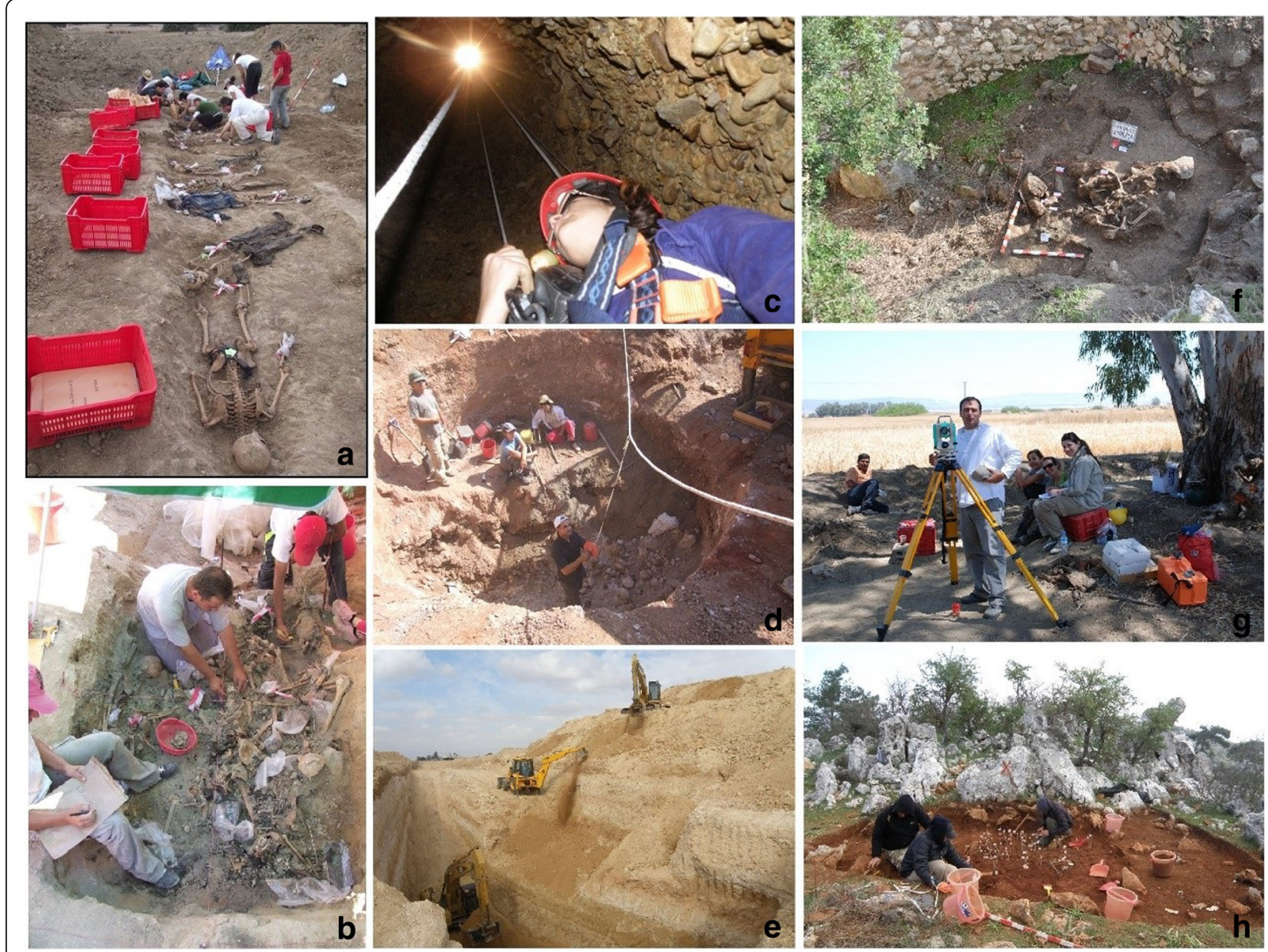

Fig. 2 From top to bottom: (a) a mass grave exhumation with the EAAF in 2007, (b) an exhumation of commingled remains, (c) an archaeologist entering a well, (d) an exhumation inside a well, (e) creating terraces during a deep well excavation, (f) an exhumation inside a kiln, (g) recording a site with total station, (h) exhumation of a shallow burial on a mountain

the archaeological phases (Ktori et al. 2016), as well as the methodical work followed to establish the biogeographical context (Haglund and Sorg 2002). The overall discipline that characterises the field teams is demonstrated through their work in cases of mass graves, complex well excavations (Çeker and Stevens 2015), ${ }^{46}$ and the establishment of new excavation methods (Ktori et al. 2016 (Fig. 2).

The field teams have excavated more than 1000 sites in 10 years and have encountered a plethora of practical difficulties. Several of these sites are considered hazardous, and the CMP has addressed this issue decisively by training the staff (especially for identifying unexploded ordinance and asbestos in excavations). They have established a team specifically for excavations with asbestos, with the rigorous application of all related health and safety regulations. There are regular visits by the Health and Safety Coordinator in the field, and a health and safety plan has been implemented in every excavation.
As a result, the field operations have been conducted with the utmost safety, even in the most difficult terrains.

\section{d) Anthropological phase}

In 2006, a small number of anthropologists were employed by the CMP to form its forensic anthropological team. They had participated in the early field operations and began analysing skeletal remains as soon as the CAL was established. Between 2006 and 2008, the anthropological team was coordinated by an EAAF expert, and in 2008-2011 by a CMP anthropologist. In 2011 and 2012, more staff was hired and divided into two anthropological teams that perform simultaneous analyses, resulting in an immediate increase in analytical capacity. Since 2012, there have been two coordinators at the CAL, one from each respective community (Fig. 3). 


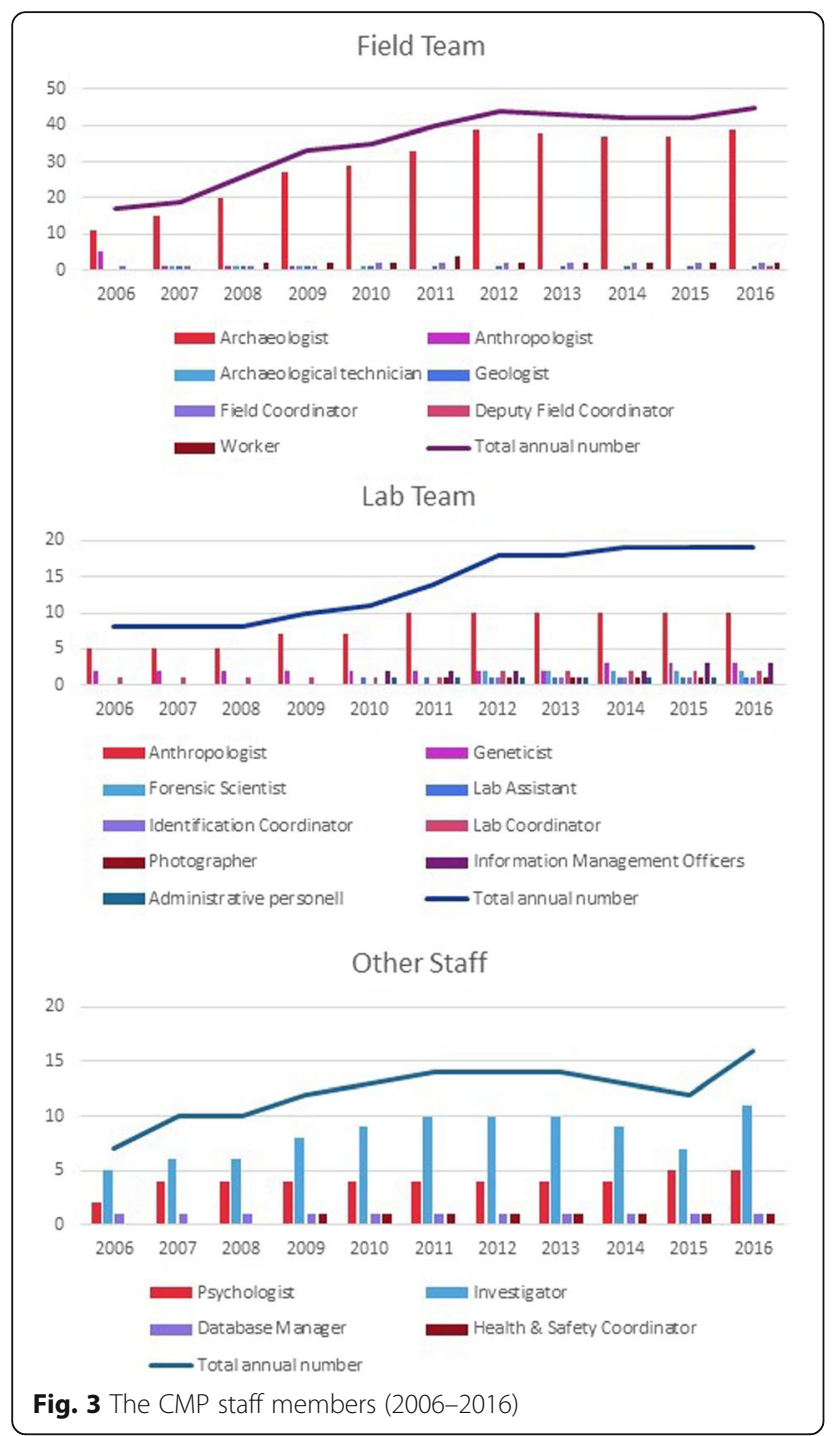

The CAL has four main functions: a) to receive the remains exhumed during the field operations, b) to conduct forensic anthropological analyses on the human remains and the material evidence, c) to recommend the identification of an individual via the Identification Coordinator in conjunction with the CAL Genetics Unit to the CMP Members, and d) to return the identified remains to the family of the missing person via the respective CMP Member's office.

Between 2006 and 2008, the anthropologists were trained by the EAAF coordinator in a variety of cases, ranging from remains recovered in an anatomical position to the reconstruction of commingled remains and remains from mass burials (Fig. 4). Skeletal remains are analysed to establish the physical characteristics, and, along with dental remains, they are used to determine an individual's biological profile. The anthropologists are always working in blind analysis to maximize impartiality and reduce confirmation bias in the tests conducted.
The anthropologists follows international standards for the analysis of skeletal remains (Byer 2005), which are communicated in the SOPs. Everything is checked, chain of custody forms are signed, and the CMP photographer takes the laboratory entry photographs. Then, the remains and artefacts are packed, labelled, and identified with a location on a printed plan of the storage facility until analysis.

There are three phases of analysis: a) initial, b) intermediate, and c) final. For the initial phase, the remains and artefacts are cleaned, labelled based on the field records, and photographed. An anthropological report is then prepared to describe them. The intermediate phase has varied complexity, as articulated skeletons are less complex than cases of commingled remains or mass or disturbed burials. Articulation of the remains requires different analytical strategies, as commingled or disturbed remains are associated with bodies or body parts by pair matching, reconstruction, or a process of elimination. Again, every step of the process is photographed and recorded in a report. At this point, the anthropologists analysing the remains select the bone samples they should cut and send to the DNA laboratory for DNA and kinship analysis. In the final phase, the anthropologist can make final changes before completing the analysis and proceeding with the results to the genetic phase. The final phase also includes the compilation of a catalogue of unassociated artefacts that is shown to families during the family viewing meetings (Moyssi et al. 2016).

\section{e) Genetic phase}

The identification of missing persons would not typically have been possible without acquiring DNA samples from their relatives. The CMP initially collaborated with the Cyprus Institute of Neurology and Genetics to collect blood or buccal samples which would then be used in DNA extraction and profiling of the relatives. It then became possible to establish the "Family Relatives' Samples Database". Later on, the CMP contracted the DNA Laboratory of the International Committee on Missing Persons (2012-2014) and Bode Cellmark Forensics (from 2014 onwards) to perform the genetic analyses required for the kinship match reports. These are sent to the CAL Genetics Unit, which is staffed by two geneticists who interpret and confirm the results. The samples must reach a threshold equal to or greater than $99.95 \%$ to produce a positive identification match.

\section{f) Identification of the remains}

Once the anthropological and genetic analyses are concluded, the CMP enters the reconciliation stage. In this sixth stage of the identification process, a team of scientists representing all involved disciplines (the 

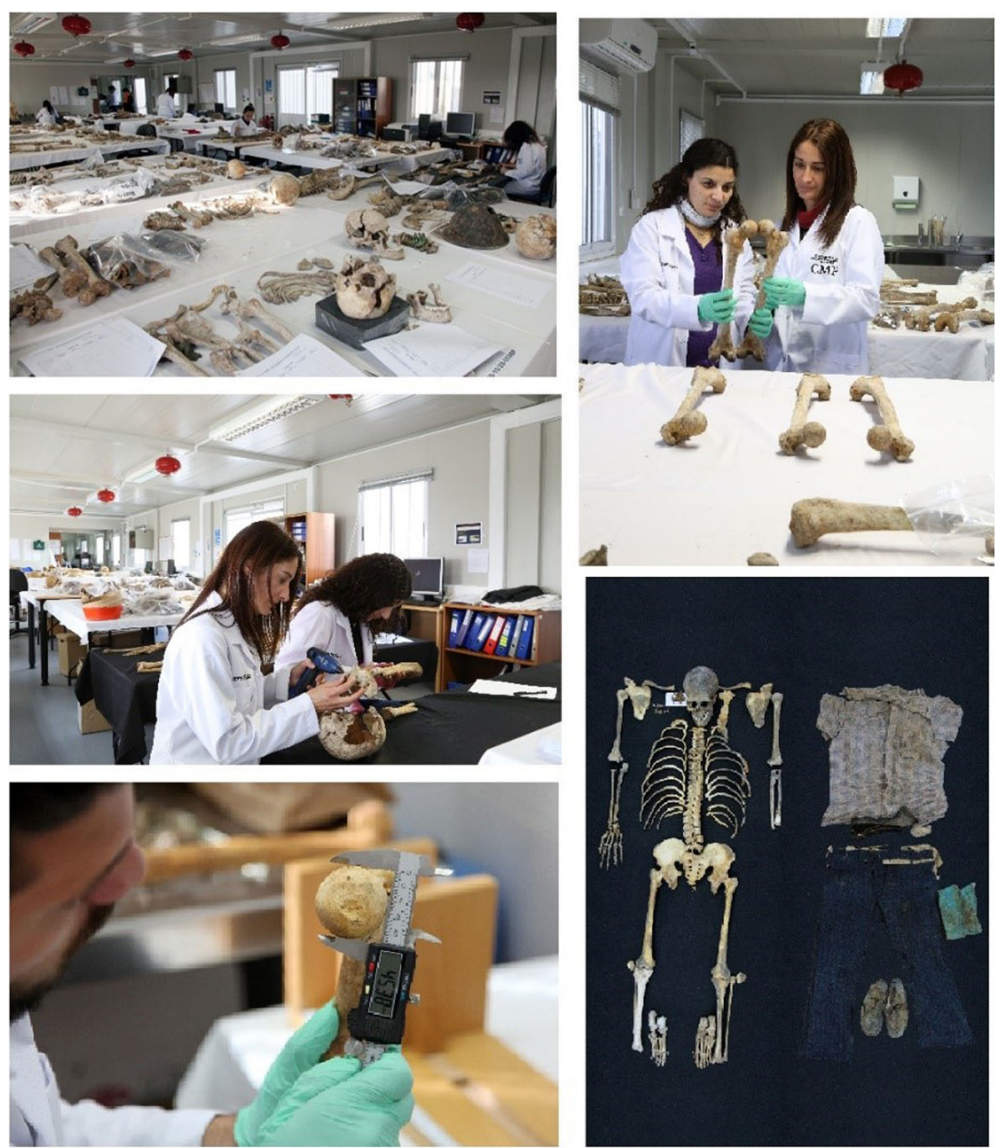

Fig. 4 The anthropological analyses conducted at CAL, resulting in the positioning of a skeleton in an anatomical position with associated artefacts

archaeologist responsible for the archaeological report, the anthropologist who analysed the case, the geneticist, and the laboratory coordinator) convene to discuss the findings. The team reviews all the data related to the case: the antemortem data, the witness and archival information, the archaeological report, and the anthropological and DNA analysis results. Since 2012, the reconciliation meetings have been supervised by the Identification Coordinator, who examines and ensures that all protocols were followed in every identification stage and that the evidence on the missing person's identity is conclusive (Fig. 5).

\section{g) Return and burial of the remains}

Once the reconciliation stage concludes successfully, only then does the CMP proceed to the final stage, where a psychologist informs the family of the missing regarding the outcome. The family is invited to the CAL, where a team of scientists present the findings to the relatives and explain each stage of the process that led to the identification. The affected relatives are always supported by a psychologist throughout the identification process, especially during the viewings, as it affects them considerably (Moyssi et al. 2016). The psychological support provided to the relatives and the active participation of the CMP scientists until the release of the remains can be considered an integrated system that meets the needs of a humanitarian investigation and the affected families, a critical element that exists in other international examples (Keough et al. 2004).

\section{The CMP's public outreach efforts}

In 2010, the CMP produced a short film entitled Digging for a Future, in which the scientists speak about their work and are filmed during its various phases (Committee on Missing Persons in Cyprus 2010). This was the first act of public outreach since the beginning of the programme. Considering its humanitarian nature and the questions which had been raised on various aspects, the CMP proceeded with the necessary sensitivity to address the matter. In April 2014, the CMP held an all-day event entitled "Searching for our Missing". This was the first time the scientists had the opportunity to interact with the public and the relatives of the missing. The 


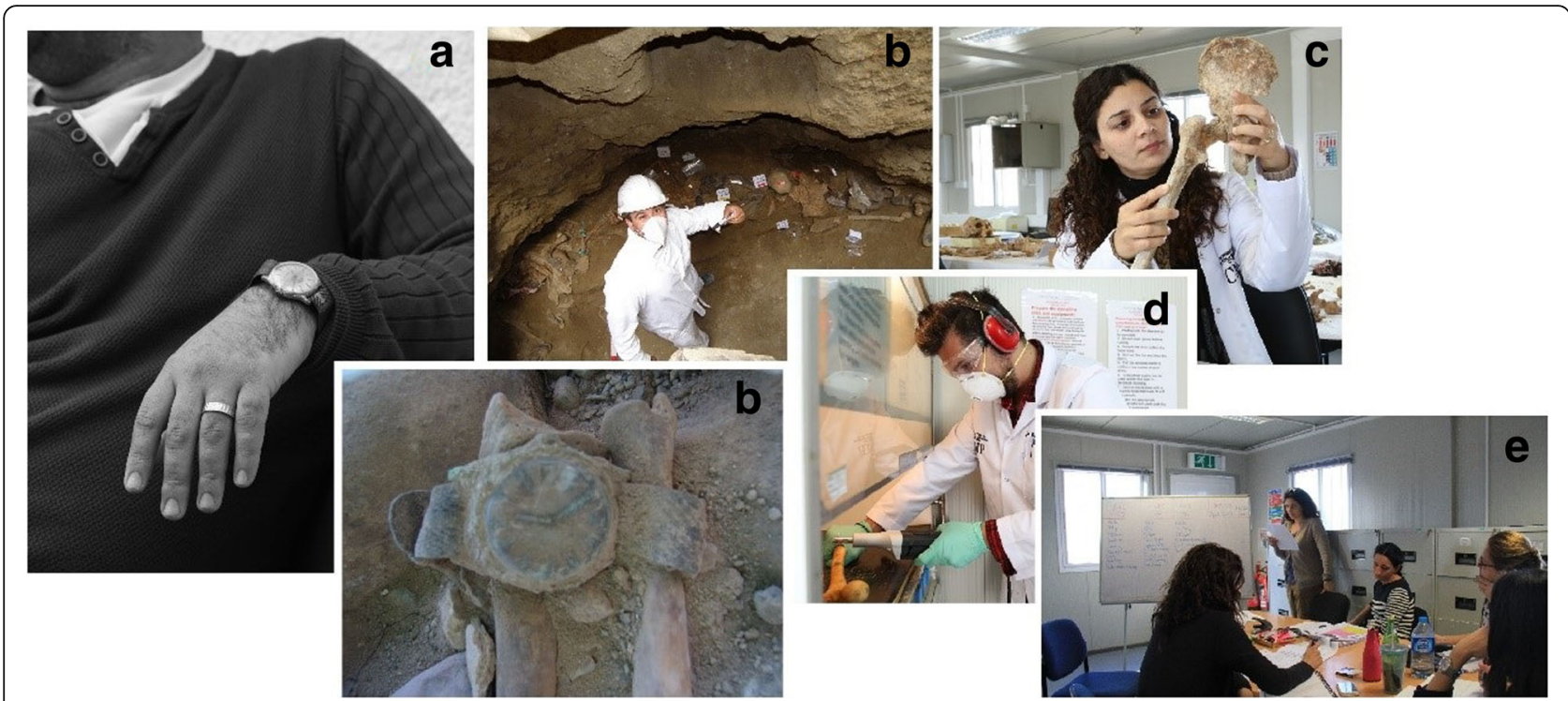

Fig. 5 The stages of the CMP forensic identification analyses: (a) the antemortem information on a missing person, (b) the exhumation of remains and encountering an artefact on the individual, (c) anthropological analysis, (d) preparation of skeletal sample for DNA testing, (e) the reconciliation meeting

event allowed the public to familiarise themselves with the CMP itself and the identification process. Most importantly, they were introduced to the group of Cypriot scientists who had been working tirelessly to provide them with the answers they had been seeking since the 1960s and 1970s.
The CMP has also participated in the Europe Day Festival since 2014, where the scientists have successfully presented the CMP project and actively engaged with the public. Furthermore, the CMP Members have increased their efforts to raise awareness in the European Parliament and the European Commission.

\section{CMP Donors 2006 - 2016}

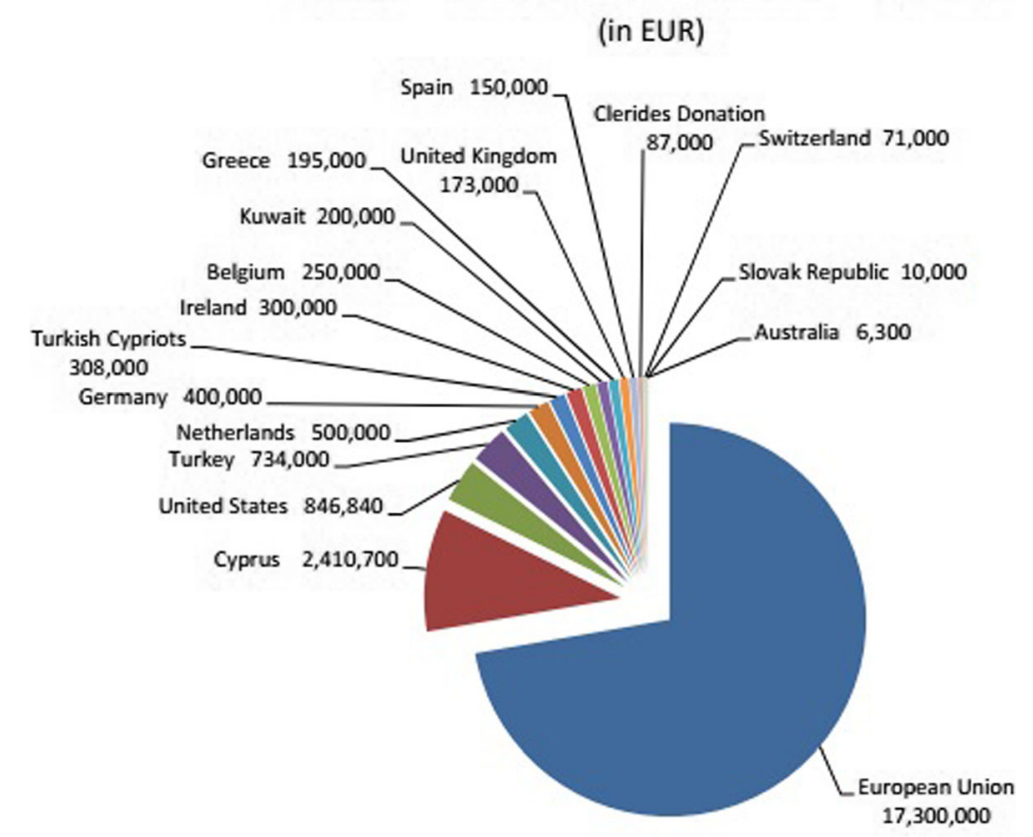

Fig. 6 The CMP donors (2006-2016) 

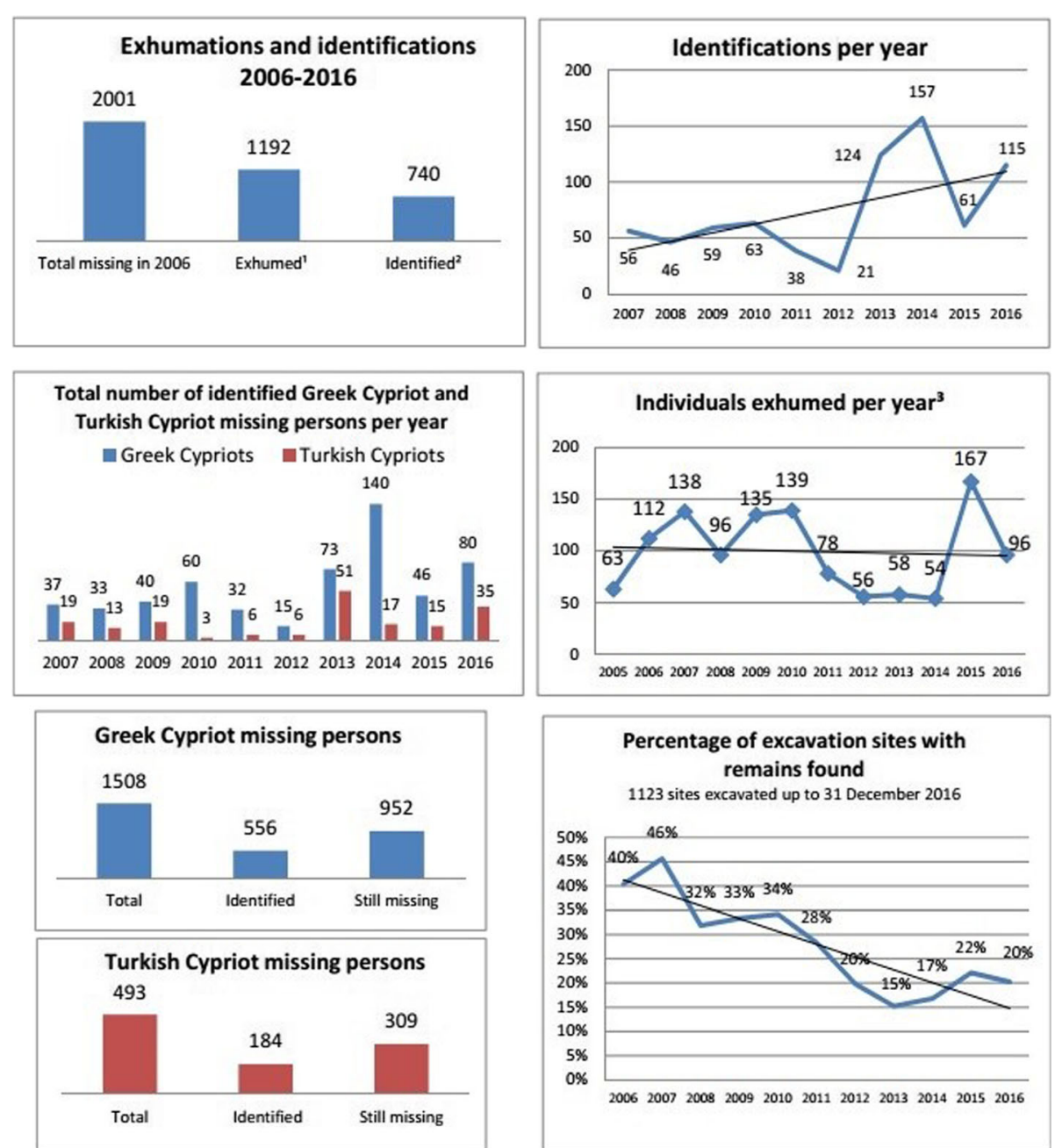

Fig. 7 The statistics on annual exhumations, identifications, and the recovery rate of human remains, and the identified missing persons

The culmination of these efforts was the hosting of the CMP exhibition "Beneath the Carob Trees: The Lost Lives of Cyprus" in 2016 at the United Nations Headquarters in New York with the SecretaryGeneral, at the European Parliament in Brussels with the Presidents of the European Parliament and Commission, and at the United Nations headquarters in Geneva with the Director-General of the United Nations Office in Geneva and the President of the ICRC. On all three occasions, the photo exhibition was combined with the launch of a book of the same name as a means of reaching a greater number of diplomats, parliamentarians, humanitarians and other people who can support this humanitarian cause.

The recognition of the CMP as a model organisation led to the formation of a successful partnership with the ICRC. In 2013, the CMP became a training and study centre for scientists and stakeholders, providing specialised practical training to more than 30 scientists from the Middle East. The strong bonds between the CMP and the ICRC, as well as the EAAF, led to the formal memoranda of understanding amongst these organisations in early 2017 (Committee on Missing Persons in Cyprus 2017a, 2017b). The CMP has also provided internship opportunities since 2012. The interns have the opportunity to train at the lab or field, or a combination of both, as a means of gaining practical experience in applied Forensic Anthropology and Archaeology. Of course, nothing would have been realised without the continuous support of our donors, particularly the European Union, which has funded the programme generously from its inception until today (Fig. 6). Without their financial support, the CMP would be unable to alleviate the pain of many Cypriot families who have spent decades enduring uncertainty over the fate of their loved ones or to assist the reconciliation process between the two communities. 

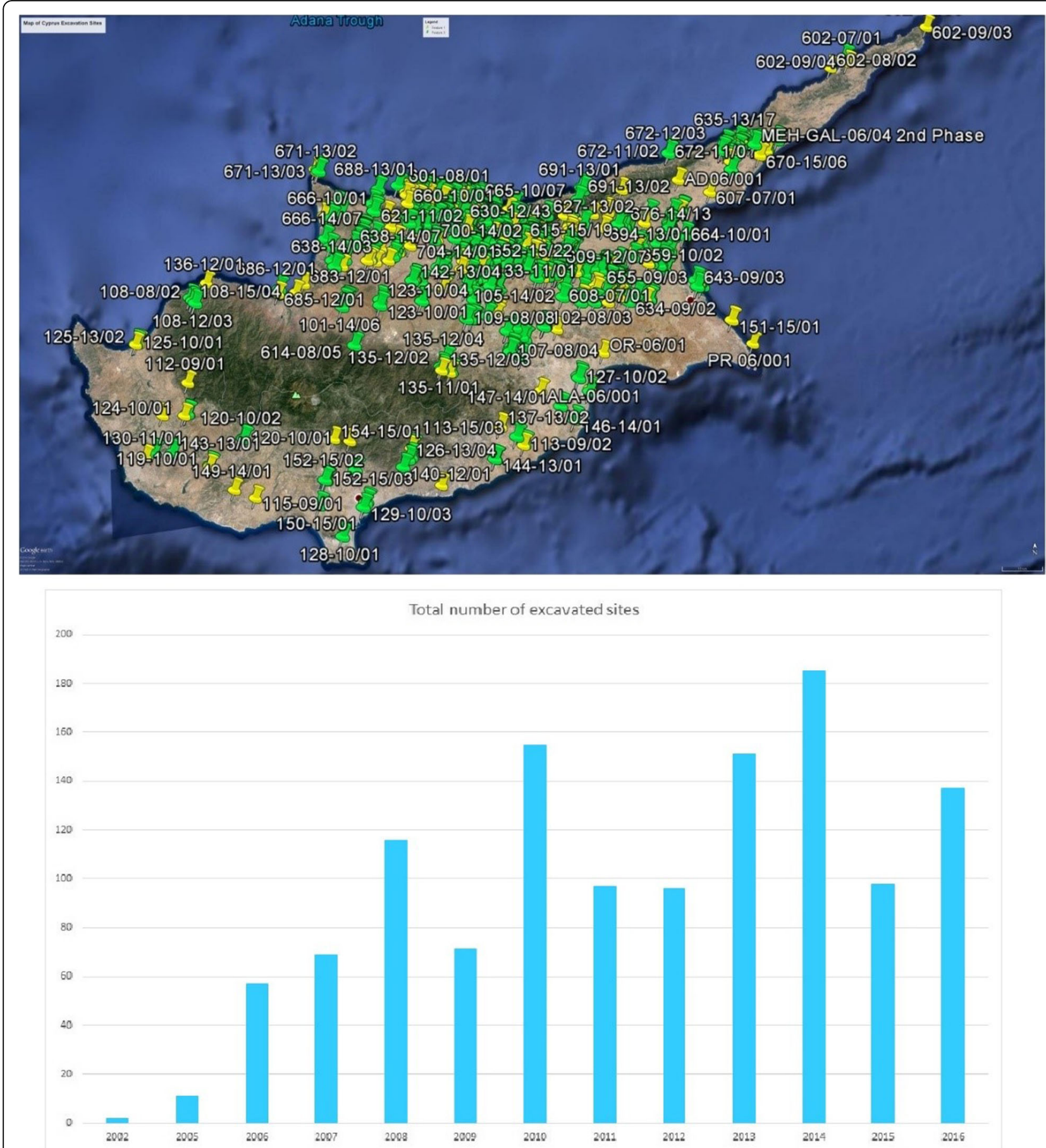

Fig. 8 The CMP excavations (2006-2016) on a Google Earth interface (top) and the statistical analysis per annum and district (bottom)

\section{Results}

The early involvement of the EAAF created the necessary mechanisms for the scientists to work under, and employ in all cases, rigorous protocols in every stage of the identification process. Despite the difficulties and challenges the scientists have faced, it became an autonomous team that operates incessantly throughout the year and has developed significantly during these 10 years of operations.

The overview of the available data has shown the following: a) the CMP has initiated the review of archival material from international and local bodies in the investigation stage, b) there has been an increase in staff numbers and thus an increase in field and lab teams, c) 
the increase in staff numbers has enhanced the capacity and multidisciplinary character of the field and lab teams, d) the increase in field teams has resulted in an increased number of annual excavations, e) the decade of CMP operations has established it as a key player in human identification, and f) the CMP has a proven that it plays a positive role in the reconciliation process in Cyprus.

Between 2006 and 2016, the archaeologists excavated 1123 sites and recovered the human remains of 1192 individuals (Committee on Missing Persons in Cyprus 2016b). The increase in the annual number of excavations (e.g. 57 excavations in 2006 compared to 155 in 2010) reflects the increase in staff numbers, particularly in the years 20102012 (Fig. 3 and 7). Within 6 years (2006-2012), it became possible to increase the number of teams, starting with one team in 2006 and having nine teams since 2012. This has positively affected the operational capacity of the field teams and enabled them to excavate more areas, with an average of approximately 100 forensic archaeological excavations annually (Fig. 8). Of course, the increase in field teams and the number of sites excavated has influenced the exhumation success rate. Therefore, the success rate of 2006, with a single team excavating 57 locations, appears to have been higher than that of 2013, when nine teams excavated 151 locations (40\% success in 2006, $15 \%$ success in 2013).

The lower success rates reflect the problems the CMP faces, namely, the decreasing number of witnesses who can provide accurate and reliable information. The CMP and the leaders of the two communities have often appealed on this matter to the public, while the CMP has taken measures to remedy the problem. The integration of geophysical methods and remote sensing techniques (e.g. ground-penetrating radar), satellite imagery, and the use of drones for aerial imagery are some of the methods currently tested in field operations. The primary goal is to establish the most successful method for locating clandestine burials to increase the annual exhumation numbers.

\section{Discussion}

Reflecting upon today's changing world, one realises that there are still problems requiring humanitarian action. One of the greatest problems is the everincreasing number of missing persons. Even when people can no longer be reunited with their loved ones, the certainty of a relative's death is preferable because it enables the survivors to mourn and recover. The Cypriot experience of 2001 missing persons from the two conflicts resulted in the establishment of a programme to recover, identify and return the remains to their families. From 2006 to 2016, the remains of 1192 individuals were exhumed through the Project on the Exhumation, Identification and Return of Remains of Missing Persons of the Committee on Missing Persons in Cyprus. ${ }^{1}$

The CMP is a successful project in Cyprus where Greek Cypriots and Turkish Cypriots have been working together on a daily basis for more than a decade. Both communities exchange best practices and serve as a model for cooperation (Arni et al. 2016). The programme promotes peace by identifying and returning missing persons to their families. This gives the necessary closure and thus continuously lowers an important barrier for reconciliation. Previous research has shown that memorialisation and remembrance are fundamental in tragedies that traumatise societies. Yet, the acknowledgement of the death of people can serve as a constant example of past mistakes that future generations should refrain from repeating (Robins 2014). The CMP's public outreach efforts have displayed exactly that, while its work has demonstrated that positive outcomes from such public events could be further extended and better incorporated in the island-wide effort of healing historical trauma. Of course, the ultimate effort of healing the trauma would be the determination of the fate of every missing person, which has been the CMP's primary goal from the very beginning.

\section{Conclusions}

The research conducted by the authors elucidated key stages in the inception and establishment of the CMP. The authors were able to highlight the development of every phase of the identification process and to demonstrate the rigorous processes applied by the scientists that ensure the quality of the identification results. The development of the programme transcends the scientific level, as the CMP serves as a model for cooperation in a post-conflict environment. Its primary goal has remained the same throughout the years, to determine the fate of all missing persons. The authors were able to demonstrate that the programme had the necessary dynamic to evolve into a key player in the field of human identification both nationally and regionally.

\section{Endnotes}

${ }^{1}$ The numbers refer to the years 2005-2016, which were pertaining to this article. Please refer to the official website for the latest progress, at www.cmp-cyprus.org.

\section{Abbreviations}

BCFT: Bi-Communal Forensic Team; CAL: CMP Anthropological Laboratory; CMP: Committee on Missing Persons in Cyprus; EAAF: Equipo Argentino de Antropología Forense (Argentine Forensic Anthropology Team); GIS: Geographic Information Systems; ICRC: International Committee of the Red Cross; SOP: Standard Operating Protocols 


\section{Acknowledgements}

The authors would like to thank the Members of the Committee on Missing Persons in Cyprus (Mr. Paul-Henri Arni, Mrs. Gülden Plümer Kuçük, Mr. Nestoras Nestoros), for facilitating their research and sponsoring their participation in the 2nd Forensic Middle East Congress. Moreover, the authors would like to sincerely thank the scientists of the Bi-communal Forensic Team, as their hard work and continuous efforts provided them with the necessary data to carry out their research and write this paper.

Presented in part at the 2 nd Annual International Congress of the International Association of Law and Forensic Sciences (IALFS), 17-19 January 2017, in Cairo, Egypt. The views expressed in this text are those of the authors and not necessarily those of the CMP.

\section{Funding}

The authors did not receive any funding to carry out this research. They were only sponsored by the Committee on Missing Persons in Cyprus to participate in the 2nd Forensic Middle East Congress and present their results.

\section{Availability of data and materials}

The data and materials are protected by the Committee on Missing Persons in Cyprus confidentiality protocols, and are not accessible to the general public.

\section{Authors' contributions}

The authors worked jointly on every section of the paper. Both authors read and approved the final manuscript.

\section{Ethics approval and consent to participate}

Not applicable.

\section{Consent for publication}

Consent to publish was obtained from all participants.

\section{Competing interests}

The authors declare that they have no competing interests.

\section{Publisher's Note}

Springer Nature remains neutral with regard to jurisdictional claims in published maps and institutional affiliations.

\section{Author details}

${ }^{1}$ Cardiff University, Cardiff, UK. ${ }^{2}$ University of Cyprus, Nicosia, Cyprus.

${ }^{3}$ Aglantzia, Cyprus. ${ }^{4}$ University of Glascow, Glasgow, UK.

Received: 27 July 2017 Accepted: 28 February 2018

\section{Published online: 06 March 2018}

\section{References}

Arni P-H, Küçük GP, Nestoros N (2016) Ten years of CMP operations [personal interview], Nicosia

Byer SN (2005) Introduction to forensic anthropology: a textbook. Pearson Education Inc, Boston

Çeker D, Stevens WD (2015) Recovery of missing persons in Cyprus: heavy equipment methods and techniques for complex well excavations. J Forens Sci 60(6):1529-1533

Committee on Missing Persons in Cyprus (2006). Press release: July 2006. http:// www.cmp-cyprus.org/sites/default/files/press_release_03.07.06.pdf. Accessed 01 Jan 2018

Committee on Missing Persons in Cyprus (2010) Digging for a future [documentary video]. Committee on Missing Persons in Cyprus, Nicosia

Committee on Missing Persons in Cyprus (2015a) Terms of reference and mandate. http://www.cmp-cyprus.org/ about-the-cmp/terms-of-referenceand-mandate/. Accessed 01 Jan 2018

Committee on Missing Persons in Cyprus (2015b) Origins. http://www.cmpcyprus.org/content/origins. Accessed 01 Jan 2018

Committee on Missing Persons in Cyprus (2015c) Partners and cooperation. Available from: http://www.cmp-cyprus.org/content/partners-andcooperation. Accessed 01 Jan 2018
Committee on Missing Persons in Cyprus (2016a) Press release: CMP initiates in-depth search of archives in Cyprus and abroad. http://www.cmp-cyprus.org/sites/default/ files/cmp_initiates_archival_research_280716. Accessed 01 Jan 2018

Committee on Missing Persons in Cyprus (2016b) Facts and figures: December 2016. http://www.cmp-cyprus.org/media/attachments/Quick\%20Statistics/ CMP_Facts_and_Figures_December_2016. Accessed 01 Jan 2018

Committee on Missing Persons in Cyprus (2017a) Press release: CMP signs cooperation agreements with the International Committee of the red Cross and the Argentinian forensic anthropology team. http://www.cmp-cyprus. org/sites/default/files/presse_release_two_mous_0. Accessed 01 Jan 2018

Committee on Missing Persons in Cyprus (2017b) Strategy. Committee on Missing Persons in Cyprus, Nicosia, pp 2017-2020

Crist TAJ (2001) Bad to the bone? Historical archaeologists in the practice of forensic science. Hist Archeol 35(1):39-56

Dirkmaat DC, Adovasio JM (1997) The role of archaeology in the recovery and interpretation of human remains from an outdoor forensic setting. In: Haglund WD, Sorg MH (eds) Forensic taphonomy: the postmortem fate of human remains. CRC Press, Boca Raton

Doretti M, Snow C (2008) Forensic anthropology and human rights. The argentine experience. In: Steadman D (ed) Hard evidence: case studies in forensic anthropology. Routledge, London and New York

EAAF (2009) Cyprus. In: EAAF (ed) EAAF 2007-2009 triannual report. EAAF, Buenos Aires and New York

Fondebrider L (2015) Forensic anthropology and the investigation of political violence. Lessons learned from Latin America and the Balkans. In: Ferrandiz F, Robben Antonius CGM (eds) Pennsylvania studies in human rights: Necropolitics: mass graves and exhumations in the age of human rights. University of Pennsylvania Press, Philadelphia

Fondebrider L, Scheinsohn V (2015) Forensic archaeology: the Argentinian way. In: WJM G, Márquez-Grant N, Janaway RC (eds) Forensic archaeology: a global perspective. Wiley Blackwell, Sussex

Haglund WD, Sorg MH (2002) Advancing forensic taphonomy: purpose, theory and process. In: Haglund WD, Sorg MH (eds) Advances in forensic taphonomy: method, theory, and archaeological perspectives. CRC press, Boca Raton

James SH, Nordby JJ (eds) (2003) Forensic science: an introduction to scientific and investigative techniques. CRC Press, Boca Raton

Keough ME, Simmons T, Samuels M (2004) Missing persons in post-conflict settings: best practices for integrating psychosocial and scientific approaches. Perspect in Public Health 124(6):271-275

Ktori M, Moyssi N, Kahraman D, Korkmaz E (2016) Methodology issues of forensic excavations at coastal sites: the experience of the committee on missing persons in Cyprus. J Greek Archaeol 1:385-402

La Haye E (2008) War crimes in armed conflicts. Cambridge University Press, Cambridge

Moyssi N, Ktori M, Vehit U (2016) Forensic management of artifacts in human identification: the experience of the committee on missing persons in Cyprus. J Forens Identif 66(3):209-231

Ousley SD, Hollinger RH (2012) The pervasiveness of Daubert. In: Dirkmaat DC (ed) A companion to forensic anthropology. Blackwell Publishing, Sussex

Rathbun TA, Buikstra JE (eds) (1984) Human identification: case studies in forensic anthropology. Charles C. Thomas, Springfield, p 7

Robins S (2014) Constructing meaning from disappearance: local memorialisation of the missing in Nepal. Int J Confl Violence 8(1):1-14

Snow CC (1982) Forensic anthropology. Annu Rev of Anthropol 11:97-131

Tidball-Binz M (2012) Global forensic science and the search for the dead and missing from armed conflict: the perspective of the International Committee of the red Cross. In: Ubelaker DH (ed) Forensic science: current issues, future directions. Wiley, Sussex

Ubelaker DH (ed) (2015) The global practice of forensic science. Wiley, Sussex xxix

United Nations (1981) General assembly resolution GA/RES/36/164. United Nations, Herndon

United Nations (1998) Rome statute of the international criminal court. United Nations, Rome 